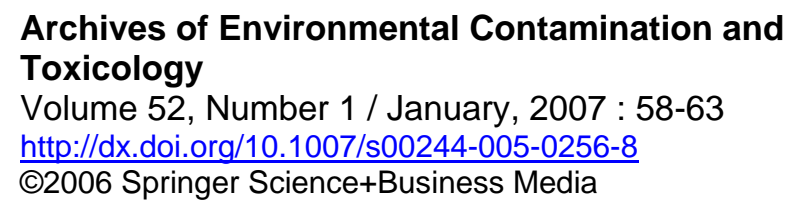

The original publication is available at http://www.springerlink.com

\title{
Impact of Diuron on Aneuploidy and Hemocyte Parameters in Pacific Oyster, Crassostrea gigas
}

\author{
Karine Bouilly ${ }^{1}$, Marc Bonnard ${ }^{1}$, Béatrice Gagnaire ${ }^{1}$, Tristan Renault ${ }^{1}$ and Sylvie Lapègue ${ }^{1}$ \\ 1 : IFREMER, Laboratoire de Génétique et Pathologie, 17390 La Tremblade, France \\ *: Corresponding author : slapegue@ifremer.fr
}

\begin{abstract}
:
Diuron is a substituted urea herbicide used for agricultural and nonagricultural weed control. Its widespread use and relatively slow breakdown led us to analyze its influence on aneuploidy level (lowered chromosome number in a percentage of somatic cells) and hemocyte parameters in Pacific oysters, Crassostrea gigas. Adult oysters were subjected to two diuron concentrations ( $300 \mathrm{ng} \mathrm{L}^{-1}$ and $3 \mathrm{\mu g} \mathrm{L}^{-1}$ ) for 11 weeks. Significantly higher aneuploidy level was observed in diuron-treated oysters compared with the control. Furthermore, the observed impact on aneuploidy persisted to the next generation as offspring exhibited significantly higher aneuploidy levels when their parents had been exposed to diuron. Significant increases in hemocyte parameters (cell mortality, phagocytosis, granulocyte percentage, reactive oxygen species, and lysosome presence) of the adults were also observed after 4 weeks of diuron exposure. The effects observed on oyster aneuploidy level and hemocyte parameters could have serious environmental and practical consequences.
\end{abstract}




\section{Introduction}

Diuron [3-(3',4'-dichlorophenyl)-1,1-dimethylurea] is a phenylurea herbicide (Brian 1964) used for pre- and post-emergence weed control in agriculture. This herbicide may enter aquatic ecosystems by spraydrift, leaching, runoff or accidental spills (Thurman et al. 1991; Squillace and Thurman 1992). Diuron is little affected by natural degradation processes (Radosevich et al. 1975), resulting in almost permanent contamination of surface and ground waters. This situation continues in France, even though the use of diuron has been deliberately reduced since 1999. Diuron is considered as a 'Priority Hazardous Substance' by the European Commission (Malato et al. 2002). Due to its slow breakdown (a month to a year) (Wauchope et al. 1992; Okamura 2002), diuron can be found in many environments such as the soil and water (Field et al. 2003; Okamura et al. 2003).

Crassostrea gigas has a diploid chromosome number of $2 n=20$ (ThiriotQuiévreux 1986) but hypodiploid aneuploid cells are regularly found (e. $g$. Leitão et al. 2001a). Aneuploidy mainly originates from the non-disjunction of chromosomes during mitosis or meiosis (Bond and Chandley 1983; Martin and Rademaker 1990). Somatic aneuploidy in C. gigas is negatively correlated with growth rate (Leitão et al. 2001a), and some evidence has been shown for genetics influencing the level of this phenomenon (Leitão et al. 2001b). Moreover, differential chromosomal susceptibility was observed in aneuploid cells (Leitão et al. 2001c; Bouilly et al. 2005). Recently, the herbicide atrazine was shown to significantly increase levels of aneuploidy in $C$. gigas (Bouilly et al. 2003, 2004).

Mollusks have an open circulatory system which is continually exposed to the fluctuations of environmental factors including contaminants (Cheng 1981). The cellular defense system of bivalves is mediated by hemocytes which perform various actions including phagocytosis, intracellular degradation of pathogens by enzymatic hydrolysis and production of reactive oxygen metabolites (Cheng and Rodrick 1975; Pipe 1992). In invertebrates, these cellular activities may be affected by the presence of pollutants (Cheng 1988a, 1988b, 1990). Diuron has already been shown to disturb the metaphase spindle microtubules by splitting microtubule organizing centers which eventually divide into multiple poles along with the associated chromosomes (multipolar anaphase) (Chauhan et al. 1998). Thus, diuron disrupts mitosis by inhibiting polymerization of tubulin subunits of microtubules and one might expect effects like aneuploidy.

Although numerous studies have been made concerning the toxic effects of diuron in organisms such as phytoplankton (Devilla et al. 2005) and fish (Okamura et al. 2002; Saglio and Trijasse 1998), no investigation has been carried out to study the genotoxicity and the immunotoxicity of this herbicide on bivalves.

The aim of the present work was to study the genotoxicity and immunotoxicity of diuron in the Pacific oyster at concentrations equivalent to those found in the environment. We investigated whether diuron had any effect on (1) chromosome number (aneuploidy) in adults and their offspring in a controlled environment, and (2) on hemocyte parameters (cell mortality, phagocytosis, granulocyte percentage, Reactive Oxygen Species (ROS) production and lysosome presence) for adults monitored using flow cytometry. 


\section{Materials and Methods}

\section{Diuron exposure}

Pacific oysters, Crassostrea gigas, were collected at Bonne Anse, CharenteMaritime, on the French Atlantic coast. These oysters were used in an experiment performed under controlled conditions in the nearby IFREMER hatchery. As threeyear-old adults, the oysters were exposed to diuron added to seawater pumped directly from Marennes-Oléron Bay. Diuron was given by the 'Institut National de la Recherche Agronomique' (INRA, Saint-Laurent-de-la-Prée, Charente-Maritime, France). Pure seawater from Marennes-Oléron Bay was used as a control (treatment 1) and two concentrations of diuron were tested: $300 \mathrm{ng} \mathrm{L}^{-1}$ and $3 \mathrm{\mu g} \mathrm{L}^{-1}$ (treatments 2 and 3 respectively). For each treatment, two replicate tanks ( $A$ and $B$ ) were used, each containing 74 oysters for the aneuploidy study and 60 oysters for monitoring hemocyte parameters. Oysters were first acclimated to the hatchery environment for 4 weeks in raceways. The experiment was then conducted over 11 weeks in tanks without automatic water renewal. Each tank contained $130 \mathrm{~L}$ of seawater which was changed every day and maintained at $20^{\circ} \mathrm{C} \pm 1{ }^{\circ} \mathrm{C}$. Diuron, in the form of diluted solutions, was added to the tanks for treatments 2 and 3. Oysters were fed daily with a mixture of algae (Skeletonema costatum, Isochrysis galbana, Tetraselmis suecica, and Chaetoceros gracialis).

\section{Offspring of diuron-exposed oysters}

At the end of the diuron exposure, six males and six females from each treatment replicate were used to make crosses. The crosses were performed between parents from the same replicate $(1 \mathrm{~A}, 1 \mathrm{~B}, 2 \mathrm{~A}, 2 \mathrm{~B}, 3 \mathrm{~A}$ or $3 \mathrm{~B})$ using all twelve animals for mass fertilization and leading to 6 crosses in all. Gametes were obtained by strip-spawning sexually mature animals. For each fertilization, 400 million spermatozoids were added to approximately 4 million oocytes suspended in $500 \mathrm{~mL}$ of seawater. For each cross, the fertilized gametes were divided into two replicates and these were placed in 50-liter fiberglass larval tanks of sea water. Larvae from these crosses were reared for 23 days under standard conditions at $23-24^{\circ} \mathrm{C}$ and fed with a mixture of algae (Isochrysis galbana, Tetraselmis suecica and Chaetoceros calcitrans forma pumillum). Larval density was evaluated directly by microscope counts for each batch. Larval growth was studied every two or three days by measuring the size of 50 larvae using an image analysis system. Larvae were transferred to a micro-nursery when they were ready to settle. These offspring were examined for aneuploidy after six months.

\section{Chromosome preparation for aneuploidy analysis}

Oysters (adults or juvenile offspring) were incubated for 7-8 $\mathrm{h}$ in seawater containing $0.005 \%$ colchicine. The gills were then dissected in seawater, treated for 40 minutes in $0.9 \%$ sodium citrate and fixed in a freshly prepared mixture of absolute ethanolacetic acid (3:1) with two 10 min changes then two 20 min changes. Slides were prepared from a piece of gill tissue, following the air drying technique of ThiriotQuiévreux and Ayraud (1982). The preparations were stained for $10 \mathrm{~min}$ with Giemsa (4\%, pH 6.8).

\section{Aneuploidy scoring}

Chromosome counts were made directly by microscope observation (Olympus $\mathrm{BH} 2$ microscope) choosing apparently intact and well-spread metaphase cells. Cells with 
$2 \mathrm{n}=19,18$ or 17 chromosomes were considered as aneuploid. The mean percentage aneuploidy per replicate was estimated by counting 30 metaphase cells per animal in 10 animals per replicate (300 well-spread metaphase cells per replicate in total).

\section{Sampling of circulating hemocytes}

Oyster hemocytes were collected at 0, 1, 2, 4 and 11 weeks. On each occasion, ten oysters per raceway were analyzed. Hemolymph was withdrawn from the pericardial cavity using a $1 \mathrm{~mL}$ syringe equipped with a needle $(0.9 \times 25 \mathrm{~mm})$. For each oyster, 0.5-1 mL of hemolymph was collected and conserved on ice to prevent hemocyte aggregation. Hemolymph samples were pooled from five oysters giving two pools per raceway and four pools per treatment.

\section{Cell analysis by flow cytometry}

Flow cytometry protocols were as described in Gagnaire et al. $(2003,2004)$. For each sample, 3000 events were counted using an EPICS XL 4 flow cytometer (Beckman Coulter). Results were depicted as cell cytograms indicating cell size (FSC value) and cell complexity (SSC value) with the fluorescence channel(s) corresponding to the marker used. A gate was defined on the basis of FSC value in order to eliminate cell debris. The type of fluorescence recorded depended on the parameter to be monitored: ROS production, lysosomes and phagocytosis were measured using green fluorescence and cell mortality using red fluorescence. The EPICS XL 4 software allowed differentiation between supposed populations of granulocytes and hyalinocytes based on their FSC and SSC values. Mortality was quantified using $200 \mu \mathrm{L}$ of hemolymph. Hemocytes were incubated in the dark for 30 min at $4^{\circ} \mathrm{C}$ with $5 \mu \mathrm{L}$ propidium iodide ( $\mathrm{Pl}, 1.0 \mathrm{mg} \mathrm{mL}^{-1}$, Interchim). Lysosome presence was measured using a commercial kit (LysoTracker ${ }^{\circledR}$ Green DND-26, 1 mM in DMSO, Molecular Probes). A $1 \mu \mathrm{L}$ aliquot of LysoTracker was added to $200 \mu \mathrm{L}$ hemocyte suspension. Cells were incubated for 2 hours in the dark at room temperature and the reaction was then stopped by placing the tubes on ice for 5 minutes. ROS production was measured using dihydrorhodamine 123 (DHR123, Molecular Probes), specific to the superoxide anion $\mathrm{O}_{2}^{-}$. A $1 \mu \mathrm{L}$ aliquot of a DHR123 solution $(145 \mu \mathrm{M})$ was added to $200 \mu \mathrm{L}$ hemocyte suspension. Cells were incubated for 30 minutes in the dark at room temperature and the reaction was then stopped by placing the tubes on ice for 5 minutes. Phagocytosis was measured by ingestion of fluorescent beads. Two hundred $\mu \mathrm{L}$ of hemolymph was incubated for $1 \mathrm{~h}$ in the dark at room temperature with $10 \mu \mathrm{L}$ of a $1 / 10$ dilution of Fluorospheres ${ }^{\circledR}$ carboxylatemodified microspheres (diameter $1 \mu \mathrm{m}$, Interchim).

\section{Statistical analysis}

Since the number of metaphase cells evaluated per individual was the same in all the studied material (30 per individual), it was possible to test the replicate effect using a two-way ANOVA (diuron concentration and replicate effect). Results were compared between parents and offspring using a three-way ANOVA in which the effects were generation (parents or offspring) diuron concentration and replicate effect. Effects of parental treatment on the offspring hatching rate and larval growth were analyzed with non-parametric Kruskall-Wallis tests.

For hemocyte parameters, results were expressed as the percentage of positive cells. Values were normalized using an $r$ angular arcsinus $\sqrt{ }$ (percentage of positive cells) transformation before analysis. ANOVA of the hemocyte parameters 
was carried out in order to detect any effect of the diuron. When $\mathrm{H}_{0}$ was rejected, an a posteriori test was used. Significance was set at $P \leq 0.05$. For ROS and lysosomes, gates were defined from the cytograms in order to distinguish different populations according to fluorescence intensity. Three cell populations were defined as follows: a population of negative cells, a population of moderately stained cells and a population of strongly stained cells (Gagnaire et al. 2006). For both ROS and lysosomes, statistical analysis was only made on strongly stained cells.

Statistical analyses were performed using the computer programs Statgraphics $^{\circledR}$ Plus version 5.1 and SYSTAT 9.0 by SPSS (Wilkinson 1990).

\section{Results}

Mortality and developmental parameters

Mortality rates of adult oysters ranged from 0 to $5.4 \%$ except for the replicate $3 \mathrm{~A}$, where this was higher $(31.3 \%)$. The hatching rates in offspring batches bred from parents exposed to 0 (control), $300 \mathrm{ng} \mathrm{L}^{-1}$, and $3 \mu \mathrm{g} \mathrm{L}^{-1}$ of diuron were $59.2 \%, 68 \%$, and $45.7 \%$, respectively (Fig. 1A). There was no significant difference in hatching rate between treatments $(F=5.34 ; P=0.06)$. The offspring of parents exposed to the two different diuron concentrations did not show any significant difference in larval growth $(P>0.05)$ (Fig. 1B).

\section{Aneuploidy}

Aneuploidy levels in adult oysters from treatments 1 (control), 2 (300 ng L ${ }^{-1}$ ) and 3 (3 $\mu \mathrm{g} \mathrm{L}^{-1}$ ) ranged from 7.3 to $10 \%, 16.3$ to $16.7 \%$, and 14.7 to $15.7 \%$, respectively (Fig. 2). One chromosome per cell was more often lost than 2 or 3 (Table 1). Treatment effect was significant $(F=13.658 ; P<0.001)$ and there was no significant difference between replicates $(F=0.115 ; P=0.736)$. Significant differences were observed between treatments 1 and $2(F=25.598 ; P<0.001)$, as well as between treatments 1 and $3(F=17.09 ; P<0.001)$, see Fig. 2. No significant difference was observed between the two diuron treatments (2 and 3) $(F=0.617 ; P=0.437)$.

Offspring aneuploidy levels ranged from 10 to $11.8 \%, 13.3$ to $14.7 \%$, and 15.9 to $17.3 \%$ for treatments 1,2 , and 3, respectively (Fig. 2). Treatment effect was significant $(F=3.547, P=0.036)$ and there was no significant difference between replicates $(F=0.137, P=0.713)$. A significant difference was observed only between treatment 1 and treatment $3(F=7.289, P=0.011)$. There was no significant difference when aneuploidy was compared between parents and offspring $(F=0.142, P=0.707)$.

\section{Hemocyte parameters}

The first significant differences in hemocyte parameters were only found after four weeks of exposure to diuron. All hemocyte parameters tested were higher in the two diuron treatments (2 and 3) than the control (1) (Fig. 3). Cell mortality was $13 \%$ in the control and $17.3 \%$ and $16.4 \%$ for $300 \mathrm{ng} \mathrm{L}^{-1}$ (treatment 2) and $3 \mu \mathrm{g} \mathrm{L}^{-1}$ (treatment 3 ) respectively $(P<0.05)$. Granulocyte percentage was $11.2 \%$ in the control and $17.2 \%$ for both diuron concentrations $(P<0.05)$. The largest differences appeared for phagocytosis: values were $37 \%$ for the control and $59.9 \%$ and $58.8 \%$ for diuron treatments 2 and 3 , respectively $(P<0.01$ between the control and the two diuron treatments). For ROS production, a similar result was observed (25.9\% for the control and $32.6 \%$ for both diuron concentrations) $(P<0.05)$. For lysosome 
detection, values were $27.7 \%$ for the control and $40.4 \%$ and $41.9 \%$ for diuron treatments 2 and 3, respectively. Although there was a significant difference between diuron-treated samples and the control $(P<0.05)$, the difference between the diuron treatments (2 and 3 ) was not significant.

Despite these clear effects after 4 weeks exposure, by 11 weeks diuron had no effects on hemocyte parameters (data not shown). Moreover, hemocyte parameters from control and contaminated oysters showed variations during the 11 weeks of experiments (data not shown).

\section{Discussion}

An effect of an environmental contaminant on aneuploidy level in Crassostrea gigas was previously demonstrated with atrazine. A positive relationship was shown between atrazine concentration and aneuploidy level in C. gigas adults and juveniles, and effects persisted to the next generation (Bouilly et al. 2003, 2004).

In the present study, a significant increase in aneuploidy level of $C$. gigas adults was observed at both diuron concentrations tested, compared with the control. Aneuploidy is a quite common response in C. gigas but observed aneuploidy levels can be more or less high. Aneuploidy levels less than $5 \%$ could be classified very weak, between 5 and $10 \%$ : weak, between 10 and $14 \%$ : normal weak, between 14 and $18 \%$ : normal high, between 18 and $30 \%$ : high, and more than $30 \%$ : very high. Observed aneuploidy levels after diuron exposure are not so high when comparing with some other studies where aneuploidy levels could exceed $30 \%$, although this was observed in slow-growing juveniles (Thiriot-Quiévreux et al. 1992). The oysters used in this study had about the same size and grew very well. With an exposure to $10 \mu \mathrm{g} \mathrm{L}^{-1}$ of atrazine (Bouilly et al. 2003), observed aneuploidy was at the same level than in that study. The number of aneuploid cells with 1 missing chromosome was higher than the ones with 2 or 3 which could be related to a lower viability of cells with only 17 or 18 chromosomes. This study is the first reported evidence of an effect of diuron, or its derived products, on aneuploidy in a bivalve. In mammalian cells, a diuron degradation product (3,4-dichloroaniline), may induce aneuploidy by interacting with the mitotic apparatus (Bauchinger et al. 1989). The concentration used in treatment $2\left(300 \mathrm{ng} \mathrm{L}^{-1}\right)$ is equivalent to that found in polluted environments. It is close to the peak value found in water from the river Vilaine (Férel, Morbihan, France) which was $440 \mathrm{ng} \mathrm{L}^{-1}$ in August 2003. The highest environmental values that have been reported were found in estuary and harbor waters, $700 \mathrm{ng} \mathrm{L}^{-1}$ and $6740 \mathrm{ng}$ $\mathrm{L}^{-1}$ respectively (Readman et al. 1993; Thomas et al. 2001). Open estuaries usually have lower environmental concentrations than harbors, due to higher water exchange (Thomas et al. 2001).

The exact mechanisms of how pesticides induce aneuploidy are not well characterized. Diuron may potentially interact with a variety of cellular targets whose modification may lead to aberrant chromosome segregation. Targets for aneugenic interactions potentially include all the components of the cell cycle (Parry and Sors 1993), and thus metabolite interactions may occur throughout it. The synthesis and formation of the microtubules and the formation of the division-spindle are of central importance in the segregation of chromosomes (Bond 1987), and hence they are potential targets for aneugenic effects of chemicals (Parry et al. 1996). Modifications in the synthesis, division and functioning of the centrioles and polar bodies or in the 
assembly and functioning of the kinetochore proteins and the centromeric DNA may also induce aneuploidy (Parry et al. 1996).

In our study, diuron did not have a significant effect on the mortality of $C$. gigas. Mortality rates were low for all three treatments. Although the mortality rate in one batch of treatment 3 was higher, this was probably due to zootechnical problems. Tanguy et al. (2005) observed no mortality when they treated oysters for 4 weeks with a mixture of three herbicides $\left(2 \mathrm{~g} \mathrm{~L}^{-1}\right.$ atrazine, $0.5 \mathrm{~g} \mathrm{~L}^{-1}$ diuron and $1 \mathrm{~g} \mathrm{~L}^{-1}$ isoproturon), even though the pollutant concentrations were much higher than those used in the present study. This agrees with results from other experiments (see review in Giacomazzi and Cochet 2004) that showed that diuron only had lethal effects on fish and aquatic invertebrates in acute exposure episodes with higher concentrations ( 1 to $42 \mathrm{mg} \mathrm{L}^{-1}$ ).

Although numerous studies have examined the effect of pesticides on hemocyte parameters, little work has been done on the effects of diuron in bivalves. Diuron induced no modification of the hsp70 promoter, a stress indicator, in human cells (Aït-Aïssa et al. 2000). However, hemocyte aggregation decreased in C. gigas when diuron $\left(1 \mu \mathrm{g} \mathrm{L}^{-1}\right)$ was tested in a mixture with other herbicides (atrazine and isoproturon) (Auffret and Oubella 1997).

Most herbicides act on photosynthesis, and both atrazine and diuron have the same mode of action on plant metabolism. They inhibit photosynthesis by reversibly binding to the $\mathrm{Q}_{\mathrm{B}}$ binding site on the $\mathrm{D}_{1}$ protein (often called the 'herbicide-binding' protein), thus inhibiting electron flow (see review by Oettmeier 1992). However, this does not suggest that herbicides would act directly on hemocyte parameters, and a previous study reported that atrazine had no effect on them (Gagnaire et al. 2003). In the present study, diuron increased all the hemocyte parameters studied (cell mortality, granulocyte percentage, ROS production, lysosome positive cells and phagocytosis), though effects were only detectable after 4 weeks of contact. Oysters may be able to respond to diuron exposure by increasing values of hemocyte parameters. We may hypothesize therefore that if hemocyte parameters are modulated, defense capacities are also be altered. After eleven weeks, diuron seemed to have no effect on hemocyte activity, suggesting that the oysters had acclimated to diuron. This kind of response has already been reported for other pollutants (Larson et al. 1989). Hemocyte parameters may recover in the long term, suggesting that mechanisms of cell restoration may possibly be at work (Russo and Lagadic 2004). Laboratory conditions could also induce a stress on hemocyte parameters as observed after a cadmium contamination in laboratory conditions (Bouilly et al. in press). Hence, variations were observed in control and contaminated oysters during the whole experiment (data not shown).

The investigation of the persistence of diuron impact on aneuploidy in the Pacific oyster is of particular importance since diuron may cause irreversible damage to genetic material. Considering the persistence of diuron in habitats adjacent to application areas, and the fact that diuron is applied preferentially in spring, pollution could negatively impact aquatic organisms during their breeding periods. It was therefore important to study the aneuploidy level of oyster offspring. We examined the offspring of the adult oysters exposed (or not) to diuron for 11 weeks, during which gametogenesis was taking place, and observed a significantly higher aneuploidy level in those bred from parents exposed to diuron compared with those bred from the control. Statistical analysis revealed no significant difference in aneuploidy level between parents and offspring in our study. The impact of diuron on Pacific oyster aneuploidy and the level of this damage therefore persist to the next 
generation. The same result has been observed with atrazine exposure (Bouilly et al. 2004). These herbicides may have a similar mode of action on the genome.

In our study, the presence of diuron in the environment of the parents did not have an effect on the hatching rate of offspring or on larval growth. In previous other studies however, diuron did affect survival and growth in amphibian embryos and tadpoles (Schuytema and Nebeker 1998), cladocerans, amphipods, midges, minnows, worms and snails (Nebeker and Schuytema 1998); although these effects were observed at concentrations higher than those used in field applications. Reproductive success of oysters exposed to diuron and condition of the offspring did not appear to be significantly affected. Thus, no physiological impairments were observed during the maturation of oysters and gamete growth. No physiological study was performed during the experiment but Photosystem II herbicides (including diuron) appear to have little direct effect on invertebrate physiology (Jones 2005), thus, it can be expected the same in oysters. Diuron has a low but measurable toxicity to aquatic invertebrates (see reviews in Jones 2005; Giacomazzi and Cochet 2004).

Our study showed that diuron worsened aneuploidy in C. gigas and that effects persisted to the next generation indicating that this herbicide may cause irreversible cytogenetic damage. Diuron also had an impact on hemocyte parameters after four weeks of exposure but this appeared to be reversible, as after eleven weeks of exposure these effects were no longer observed. However, at the tested concentrations, the diuron exposure response does not seem to be biologically relevant as parameters as mortality, hatchering rate and larval growth were not affected.

\section{Acknowledgements}

The authors are grateful to $\mathrm{C}$ Chevallier for supplying the diuron. Part of this research was realised with the IMOPHYS research group (Intégration de réponses MOléculaires et PHYSiologiques aux contaminants chimiques en milieu côtier) and supported by the Action Incitative IFREMER-INRA 2003 (C: No.03/1214839). 


\section{References}

Aït-Aïssa S, Porcher JM, Arrigo AP, Lambré C (2000) Activation of the hsp70 promoter by environmental inorganic and organic chemicals: relationships with cytotoxicity and lipophilicity. Toxicology 145:147-157

Auffret M, Oubella R (1997) Hemocyte aggregation in the oyster Crassostrea gigas: In vitro measurement and experimental modulation by xenobiotics. Comp Biochem Physiol A 118:705-712

Bauchinger M, Kulka U, Schmid E (1989) Cytogenetic effects of 3,4-dichloroaniline in human lymphocytes and V79 Chinese hamster cells. Mutat Res Lett 226:197-202

Bond DJ (1987) Mechanisms of aneuploid induction. Mutat Res 181:257-266

Bond DJ, Chandley AC (1983) Aneuploidy. Oxford Monographs on Medical Genetics No. 11. Oxford University Press, Oxford, UK

Bouilly $\mathrm{K}$, Leitão A, McCombie $H$, Lapègue $S$ (2003) Impact of atrazine on aneuploidy in Pacific oysters, Crassostrea gigas. Environ Toxicol Chem 22:229-233

Bouilly K, McCombie H, Leitão A, Lapègue S (2004) Persistence of atrazine impact on aneuploidy in Pacific oysters, Crassostrea gigas. Mar Biol 145:699-705

Bouilly K, Leitão A, Chaves R, Guedes-Pinto H, Boudry P, Lapègue S (2005) Endonuclease banding reveals that atrazine-induced aneuploidy resembles spontaneous chromosome loss in Crassostrea gigas. Genome 48:177-180

Bouilly K, Gagnaire B, Bonnard M, Thomas-Guyon H, Renault T, Miramand P, Lapègue $S$ (in press) Effects of cadmium on aneuploidy and hemocyte parameters in the Pacific oyster, Crassostrea gigas. Aquatic Toxicology

Brian RC (1964) The classisfication of herbicides and types of toxicity. In: Audus LJ (ed) The physiology and biochemistry of herbicides. London \& New York: Academic Press, pp 1-37

Chauhan LKS, Saxena PN, Sundararaman V, Gupta SK (1998) Diuron-induced cytological and ultrastructural alterations in the root meristem cells of Allium cepa. Pestic Biochem Phys 62:152-163

Cheng TC (1981) Bivalves. In: Ratcliffe NA, Rowley AF (eds) Invertebrate blood cells. Academic Press, London, pp 233-299

Cheng TC (1988a) In vivo effects of heavy metals on cellular defense mechanisms of Crassostrea virginica: total and differential cell counts. J Invertebr Pathol 51:207-214 Cheng TC (1988b) In vivo effects of heavy metals on cellular defense mechanisms of Crassostrea virginica: phagocytic and endocytotic indices. J Invertebr Pathol 51:215220

Cheng TC (1990) Effects of in vivo exposure of Crassostrea virginica to heavy metals on hemocyte viability and activity levels of lysosomal enzymes. Academic Press, San Diego, CA

Cheng TC, Rodrick GE (1975) Lysosomal and other enzymes in the haemolymph of Crassostrea virginica, and Mercenaria mercenaria. Comp Biochem Physiol B 52:443447

Devilla RA, Brown MT, Donkin M, Tarran GA, Aiken J, Readman JW (2005) Impact of antifouling booster biocides on single microalgal species and on a natural marine phytoplankton community. Mar Ecol Prog Ser 286:1-12

Field JA, Reed RL, Sawyer TE, Griffith SM, Wigington PJ (2003) Diuron occurrence and distribution in soil and surface and ground water associated with grass seed production. J Environ Qual 32:171-179 
Gagnaire B, Renault T, Bouilly K, Lapègue S, Thomas-Guyon H (2003) Study of atrazine effects on Pacific oyster, Crassostrea gigas, haemocytes. Curr Pharm Design 9:193-199

Gagnaire B, Thomas-Guyon H, Renault T (2004) In vitro effects of cadmium and mercury on Pacific oyster, Crassostrea gigas (Thunberg), haemocytes. Fish Shellfish Immun 16:501-512

Gagnaire B, Thomas-Guyon H, Burgeot T, Renault T (2006) Pollutants effects on Pacific oyster, Crassostrea gigas (Thunberg), hemocytes: screening of 23 molecules using flow cytometry. Cell Biol Toxicol 22:1-14

Giacomazzi S, Cochet N (2004) Environmental impact of diuron transformation: a review. Chemosphere 56:1021-1032

Jones R (2005) The ecotoxicological effects of Photosystem II herbicides on corals. Mar Pollut Bull 51:495-506

Larson KG, Roberson BS, Hetrick FM (1989) Effect of environmental pollutants on the chemiluminescence of hemocytes from the American oyster Crassostrea virginica. Dis Aquat Organ 6:131-136

Leitão A, Boudry P, Thiriot-Quiévreux C (2001a) Negative correlation between aneuploidy and growth in the Pacific oyster Crassostrea gigas: ten years of evidence. Aquaculture 193:39-48

Leitão A, Boudry P, McCombie H, Gérard A, Thiriot-Quiévreux C (2001b) Experimental evidence for a genetic basis to differences in aneuploidy in the Pacific oyster (Crassostrea gigas). Aquat Living Resour 14:233-237

Leitão A, Boudry P, Thiriot-Quiévreux C (2001c) Evidence of differential chromosome loss in aneuploid karyotypes of the Pacific oyster, Crassostrea gigas. Genome 44:735-737

Malato S, Blanco J, Cáceres J, Fernández-Alba AR, Agüera A, Rodríguez A (2002) Photocatalytic treatment of water-soluble pesticides by photo-Fenton and $\mathrm{TiO}_{2}$ using solar energy. Catal Today 76:209-220

Martin RH, Rademaker A (1990) The frequency of aneuploidy among individual chromosomes in 6,821 human sperm chromosome complements. Cytogenet Cell Genet 53:103-107

Nebeker AV, Schuytema GS (1998) Chronic effects of the herbicide diuron on freshwater cladocerans, amphipods, midges, minnows, worms, and snails. Arch Environ Contam Toxicol 35:441-446

Oettmeier W (1992) Herbicides of photosystem II. In: Barber J (ed) The photosystems: structure, function and molecular biology, Vol II. Elsevier, Amsterdam, pp 349-408

Okamura H (2002) Photodegradation of the antifouling compounds Irgarol 1051 and diuron released from a commercial antifouling paint. Chemosphere 48:43-50

Okamura H, Watanabe T, Aoyama I, Hasobe M (2002) Toxicity evaluation of new antifouling compounds using suspension-cultured fish cells. Chemosphere 46:945951

Okamura H, Aoyama I, Ono Y, Nishida T (2003) Antifouling herbicides in the coastal waters of western Japan. Mar Pollut Bull 47:59-67

Parry JM, Sors A (1993) The detection and assesment of the aneugenic potential of environmental chemicals: the European Community Aneuploidy Project. Mutat Res 287:3-16

Parry JM, Parry EM, Bourner R, Doherty A, Ellard S, O'Donovan J, Hoebee B, de Stoppelaar JM, Mohn GR, Önfelt A, et al. (1996) The detection and evaluation of aneugenic chemicals. Mutat Res 353:11-46 
Pipe RK (1992) Generation of reactive oxygen metabolites by the haemocytes of the mussel Mytilus edulis. Dev Comp Immunnol 16:111-122

Radosevich SR, Elmore CL, McHenry WB (1975) Herbicide persistence in irrigated soils. In: Craft SA (ed) Modern weed control. Univ California Press, Berkeley, CA, p 427

Readman JW, Albanis TA, Barcelo D, Galassi S, Tronczynski J, Gabrielides GP (1993) Herbicide contamination of Mediterranean estuarine waters: results from a MED POL pilot survey. Mar Pollut Bull 26:613-619

Russo J, Lagadic L (2004) Effects of environmental concentrations of atrazine on hemocyte density and phagocytic activity in the pond snail Lymnaea stagnalis (Gastropoda, Pulmonata). Environ Pollut 127:303-311

Saglio P, Trijasse S (1998) Behavioral responses to atrazine and diuron in goldfish. Arch Environ Contam Toxicol 35:484-491

Schuytema GS, Nebeker AV (1998) Comparative toxicity of diuron on survival and growth of pacific treefrog, bullfrog, red-legged frog and African clawed frog embryos and tadpoles. Arch Environ Contam Toxicol 34:370-376

Squillace PJ, Thurman EM (1992) Herbicide transport in rivers: importance of hydrology and geochemistry in nonpoint source contamination. Environ Sci Technol 26:538-545

Tanguy A, Boutet I, Moraga D (2005) Molecular characterization of the glutamine synthetase gene in the Pacific oyster Crassostrea gigas: expression study in response to xenobiotic exposure and developmental stage. Biochim Biophys Acta 1681:116-125

Thiriot-Quiévreux C (1986) Etude de l'aneuploïdie dans différents naissains d'Ostreidae (Bivalvia). Genetica 70:225-231

Thiriot-Quiévreux C, Ayraud N (1982) Les caryotypes de quelques espèces de bivalves et gastéropodes marins. Mar Biol 70:165-172

Thiriot-Quiévreux C, Pogson GH, Zouros E (1992) Genetics of growth rate variation in bivalves: aneuploidy and heterozygosity effects in a Crassostrea gigas family. Genome 35:39-45

Thomas KV, Fileman TW, Readman JW, Waldock MJ (2001) Antifouling paint booster biocides in the UK coastal environment and potential risks of biological effects. Mar Pollut Bull 42:677-688

Thurman EM, Goolsby DA, Meyer MT, Kolpin DW (1991) Herbicides in surface waters in the midwestern United States: the effect of spring flush. Environ Sci Technol 25:1794-1796

Wauchope RD, Buttler TM, Hornsby AG, Augustijn-Beckers PWM, Burt JP (1992) The SCS/ARS/CES pesticide properties database for environmental decisionmaking. Rev Environ Contam Toxicol 123:1-155

Wilkinson L (1990) SYSTAT: The System for Statistics. SYSTAT, Evanston, IL 
Table 1. Observed aneuploidy of Pacific oysters Crassostrea gigas (parents) exposed to different diuron treatments: treatment 1 (control $0 \mathrm{ng} \mathrm{L}^{-1}$ ), treatment 2 (300 $\left.\mathrm{ng} \mathrm{L}^{-1}\right)$ and treatment $3\left(3 \mathrm{~g} \mathrm{~L}^{-1}\right)$ and observed aneuploidy of their offspring.

Population Treatment Percentage of aneuploid cells with Mean aneuploidy

\begin{tabular}{llllll} 
& number & $2 \mathrm{n}=19$ & $2 \mathrm{n}=18$ & $2 \mathrm{n}=17$ & $(\%)$ \\
\hline Parents & 1 & 3.5 & 2.8 & 2.3 & 8.6 \\
Parents & 2 & 6.0 & 4.8 & 5.7 & 16.5 \\
Parents & 3 & 8.0 & 4.5 & 2.7 & 15.2 \\
Offspring & 1 & 6.7 & 2.6 & 1.6 & 10.9 \\
Offspring & 2 & 8.7 & 2.8 & 2.5 & 14.0 \\
Offspring & 3 & 10.0 & 4.0 & 2.6 & 16.6 \\
\hline
\end{tabular}


Fig. 1

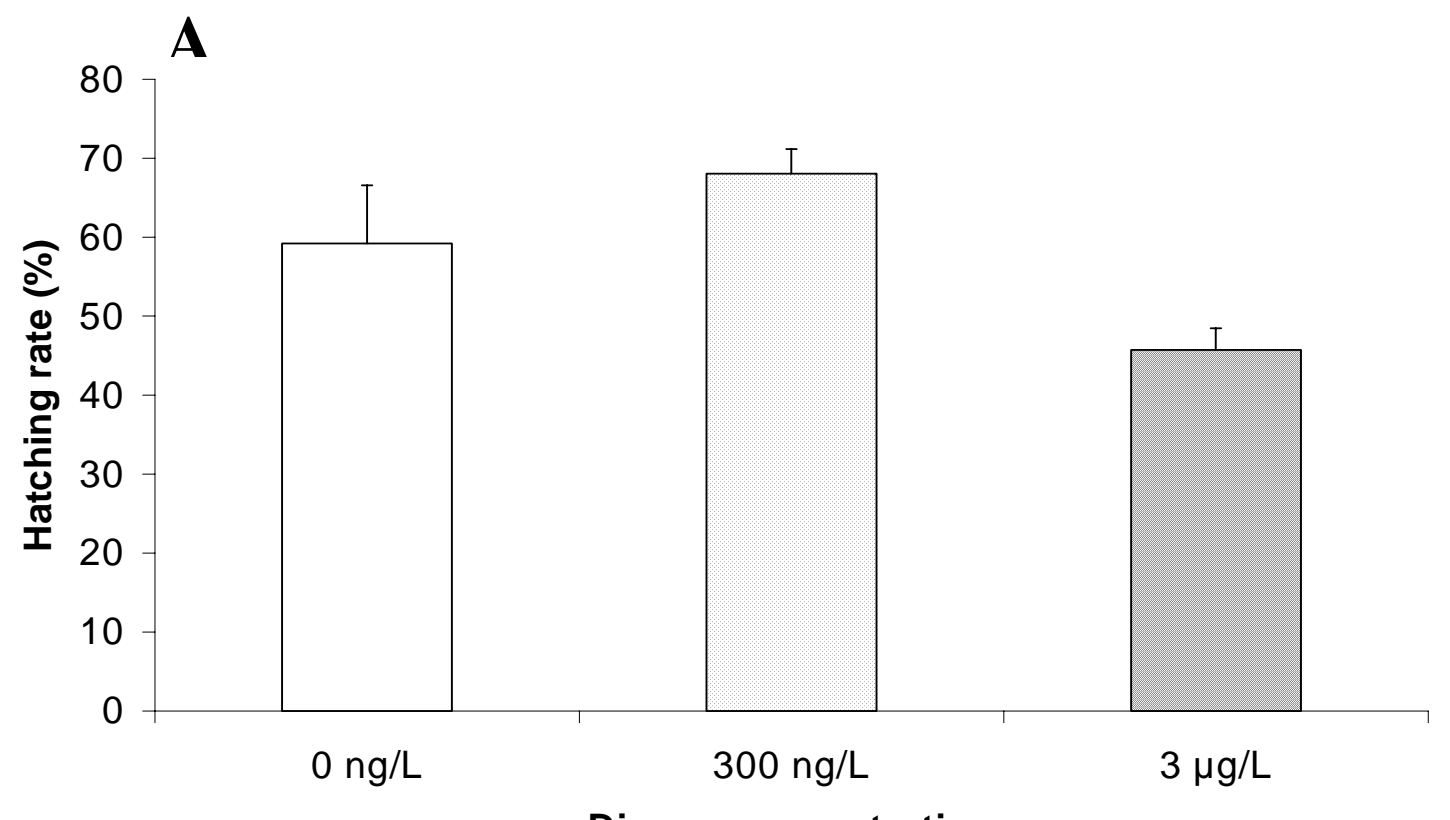

Diuron concentration

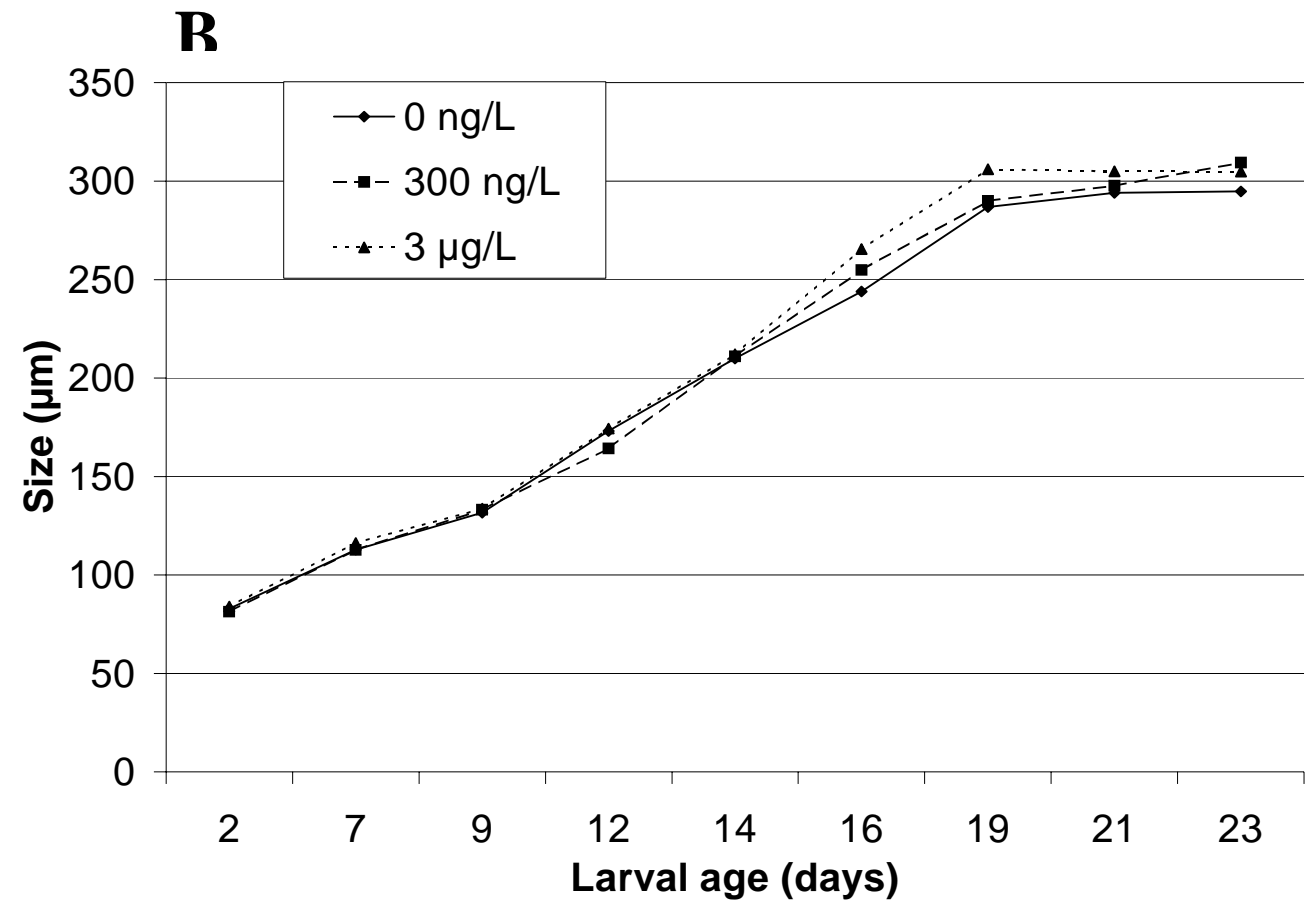

Fig. 1. A: Hatching rate (\%) of offspring of Pacific oysters, Crassostrea gigas, exposed to different diuron concentrations $\left(0,300 \mathrm{ng} \mathrm{L}^{-1}\right.$ and $\left.3 \mathrm{\mu g} \mathrm{L}^{-1}\right)$. Bars indicate standard deviation of the mean. $\mathrm{B}$ : Size $(\mu \mathrm{m})$ of larvae bred from parental Pacific oysters, Crassostrea gigas, exposed to different diuron concentrations $\left(0,300 \mathrm{ng} \mathrm{L}^{-1}\right.$ and $\left.3 \mu \mathrm{g} \mathrm{L}^{-1}\right)$. 
Fig. 2

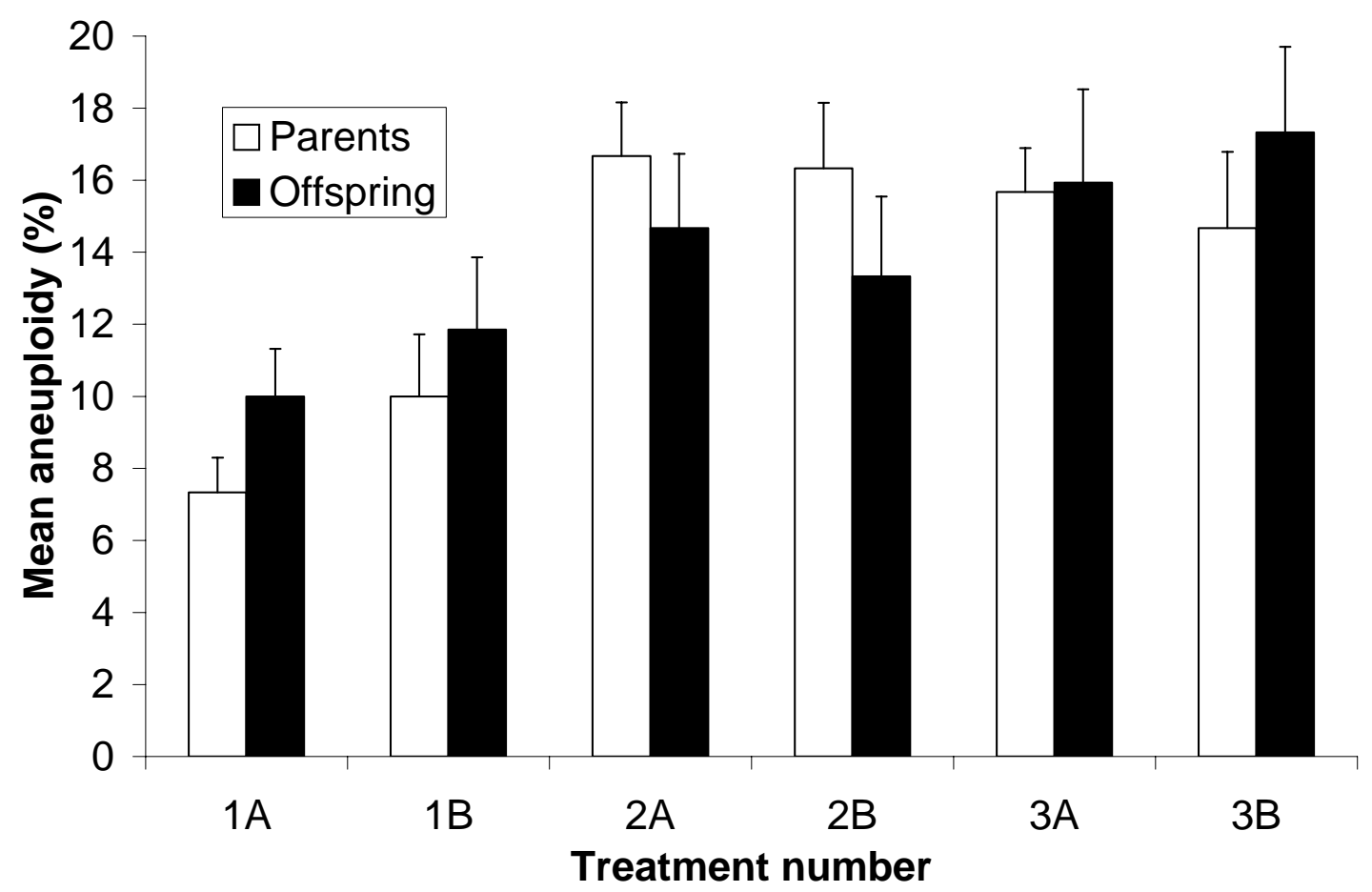

Fig. 2. Mean aneuploidy percentage of adult Pacific oysters, Crassostrea gigas, in controls ( $1 \mathrm{~A}$ and $1 \mathrm{~B})$ and diuron treatments at two concentrations (2A and 2B, $300 \mathrm{ng}$ $\mathrm{L}^{-1}$; $3 \mathrm{~A}$ and $3 \mathrm{~B}, 3 \mu \mathrm{g} \mathrm{\textrm {L } ^ { - 1 }}$ ), and of their offspring. Bars indicate standard deviation of the mean. 
Fig. 3

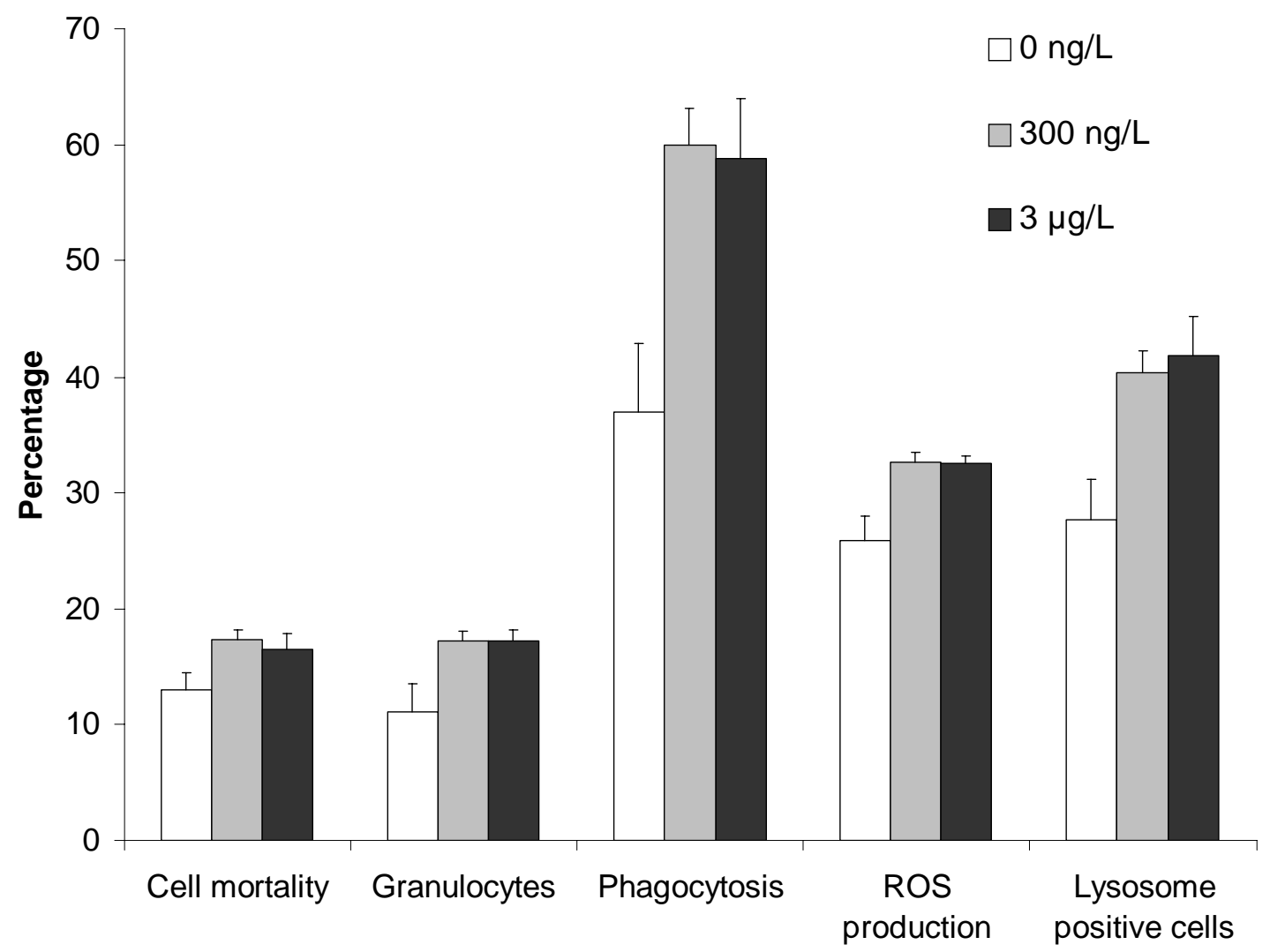

Fig. 3. Hemocyte parameters of adult Pacific oysters, Crassostrea gigas, for control $\left(0 \mathrm{ng} \mathrm{L}^{-1}\right)$ and both diuron concentrations (300 $\mathrm{ng} \mathrm{L}^{-1}$ and $\left.3 \mu \mathrm{g} \mathrm{L}^{-1}\right)$ after four weeks of contamination. Values are means of four replicate pools of five animals each. Bars indicate standard deviations of the mean. 